\title{
ORIGINAL ARTICLE How far can you go? Association between illicit drug use and academic migration
}

\author{
Até onde você pode ir? Associação entre uso de \\ drogas ilícitas e migração acadêmica \\ Lauro Miranda Demenech,2 \\ http://orcid.org/0000-0002-7285-2566 \\ Samuel C. Dumith \\ http://orcid.org/0000-0002-5994-735X \\ Luiza Santos Ferreira' \\ hitp://oridiory/0000-0002-2005-4590 \\ Mariana Lima Corrêa' \\ hteps:/lorid.ororg/0000-0003-2373-3584 \\ Pedro San Martin Soares' \\ hitps:/loridi.0.0r/0000-0001-8974-7503 \\ Priscila Arruda da Silva \\ https:/lorid.orgy/0000-0002-5359-8646 \\ Lucas Neiva-Silva $a^{1,2}$ \\ http:///orid.org/0000-0002-7526-2238
}

\section{Keywords}

Illicit drugs, academic

migration, students,

undergraduation, university.

\section{ABSTRACT}

Objective: To measure the prevalence of illicit drugs use in the lifetime, last year and last month, as well as the factors associated to the last year's use and its association with academic migration, among undergraduate students of a university in southern Brazil. Methods: In this cross-sectional study, data were collected through self-administered questionnaire. It was conducted a clustered systematic sampling. For multivariate analyses, it was used Poisson regression. Results: 1,423 students participated. The prevalence of illicit drug use in the lifetime, last year and last month were $42.4 \%, 25.5 \%$ and $17.7 \%$, respectively. Regarding illicit substances, marijuana use was the most prevalent. The variables independently associated with illicit drugs use in the last year were academic migration, being male, younger, single, high parent's educational level, living with peers, tobacco use in the last year, and having friend and relative that have used illicit drugs. Religious practice had a protective effect. Conclusion: Individuals who migrated from their cities to study at the university are more exposed to the main risk factors pointed out by this research and hence to the use of illicit drugs. Based on these results, we suggest that universities develop evaluation, prevention, treatment or referral strategies considering specific needs of this population

\section{RESUMO}

Objetivo: Medir a prevalência do uso de drogas ilícitas na vida, no último ano e no último mês, assim como os fatores associados ao uso no último ano e a sua relação com a migração

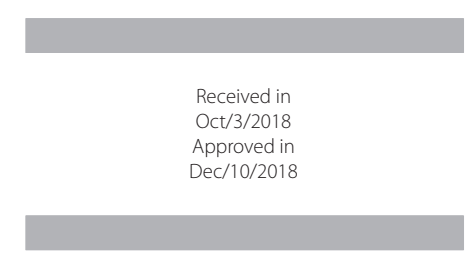

DOI: 10.1590/0047-2085000000219

1 Federal University of Rio Grande, School of Medicine, Postgraduate Program of Public Health, Rio Grande, RS, Brazil. 2 Federal University of Rio Grande, School of Psychology, Center for Studies on Risk and Health, Rio Grande, RS, Brazil.

Address for correspondence: Lauro Demenech

Av. Itália, km 8

96201-900 - Rio Grande, RS, Brazil

E-mail: lauro_demenech@hotmail.com 


\section{Palavras-chave}

Drogas ilícitas, migração acadêmica, estudantes, graduação, universidade. acadêmica, entre estudantes de graduação de uma universidade no sul do Brasil. Métodos: Neste estudo transversal, os dados foram coletados por meio de um questionário autoaplicável. Foi conduzida uma amostragem sistemática por conglomerados. Para a análise multivariável, foi utilizada a regressão de Poisson. Resultados: Foram entrevistados 1.423 estudantes. A prevalência de uso de drogas ilícitas na vida, no último ano e no último mês foi de $42,4 \%, 25,5 \%$ e 17,7\%, respectivamente. Em relação às substâncias ilícitas, o uso de maconha foi o mais prevalente. As variáveis independentemente associadas ao uso de drogas ilícitas no último ano foram a migração acadêmica, ser do sexo masculino, ser mais jovem, ser solteiro, o maior nível educacional dos pais, morar com os pares, ter feito uso de tabaco no último ano e ter amigos e familiares que já fizeram uso de drogas ilícitas. A prática religiosa teve efeito protetivo. Conclusão: Indivíduos que migraram de suas cidades para estudar na universidade estão mais expostos aos principais fatores de risco apontados nesta pesquisa e, assim, ao uso de drogas ilícitas. Com base nesses resultados, sugerimos que as universidades desenvolvam estratégias de avaliação, prevenção, tratamento ou encaminhamento, considerando as necessidades específicas dessa população.

\section{INTRODUCTION}

In 2014, one in every 20 adults around the world used at least one illicit drug, and is estimated that globally 29 million people suffer from some kind of drug-related disorder and that more than 200 thousand deaths are associated with this use $^{1}$. In Brazil, prevalence of illicit drug use in the last year was $15.5 \%$ among adults aged 18 or over ${ }^{2}$. This frequency is even higher in the university context, reaching $35.8 \%{ }^{3}$.

Entrance to university characterizes a transition period in the young adult's life 4 . Contact with new experiences and development of new social networks can increase the vulnerability of these individuals, influencing the consumption of illicit drugs $s^{4,5}$. Researches with university students indicates that male, younger, smokers and those with friends who use

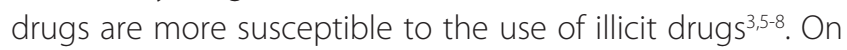
the other hand, those living with relatives and with religious practices showed a lower risk for this behavior ${ }^{5,9}$.

In 2010, there was a modification in the admission process to undergraduate courses in most public universities in Brazil. In that year, the Ministry of Education proposed the unification of the processes, through the National High School Examination (ENEM, which stands for Exame Nacional do Ensino Médio in Portuguese). This method allowed individuals to apply for universities all over the country with only one test, intending to increase equity and democratization in the access to higher education, also contributing to academic migration within the country ${ }^{10}$.

New challenges arise with increase of individuals who migrate from their cities to study at the university. The distancing from previous geographical and sociocultural background may foster a persistent deprivation of psychosocial integration and consequently the use of drugs as coping strategy ${ }^{11}$. Thus, the complex relationship between academic migration and psychosocial integration may constitute a risk factor for the illicit drug use among undergraduate students.
Therefore, the aim of this study was to measure the prevalence of illicit drugs use in lifetime, last year and last month, as well as the association of academic migration and other factors with last year's use among undergraduates of a university in southern Brazil.

\section{METHODS}

\section{Study design and participants}

This study had a cross-sectional design. It was conducted at the Federal University of Rio Grande (FURG, which stands for Universidade Federal do Rio Grande in Portuguese), which is a public higher education institution with approximately 8,000 undergraduate students in the campus of Rio Grande, Rio Grande do Sul State, Brazil.

The inclusion criteria were: to be 18 years or older, to study in any undergraduate course with presential modality at the campus of Rio Grande and to be enrolled in the year of 2015. Individuals that had abandoned the subject at the time of the data collection were considered ineligible.

\section{Sample size and sampling strategy}

We conducted a clustered systematic sampling, based on the relation of all the classes obtained in university's system. Classes were used as sampling unit. Each class consists of a group of students enrolled in the same subject. As the sampling unit were classes, design effect was taken into account $($ deff $=1.5$; parameters: intraclass correlation coefficient $=$ 0.02 , mean cluster size $=20^{3}$ ).

Two sample size calculations were performed, one for prevalence and other for associated factors. Descriptive sample size calculation resulted in 1,290 individuals (parameters: minimum expected prevalence of 10\%, margin of error of 2 percentage points, $80 \%$ of Power, $5 \%$ of significance level, plus 10\% for possible losses, and a deff of 1.5). Associated factors sample size calculation showed that it 
would be necessary 1,811 individuals (parameters: exposed/ non-exposed ratio of 1:4, prevalence ratio of $1.8,80 \%$ of Power, $5 \%$ of significance level, plus $10 \%$ possible losses and refusals, $15 \%$ for confounding factors and a deff of 1.5).

Thus, as we expected an average of 20 students per class $^{3}$, it would be necessary 91 classes (1,811 divided by 20). In addition, we added $10 \%$ to the total, to address the possibility of having individuals enrolled in two or more classes and with ages lower than 18, generating the final number of 101 classes. To compose the sample, those classes were systematically drawn respecting a selection interval previously calculated.

\section{Variables and instrument}

A self-administered and confidential questionnaire was used. We assessed use in the lifetime, last year and last month of the following substances: marijuana, inhalants, cocaine, crack, mushrooms, ecstasy, LSD (which were further categorized to make up the outcome variable "illicit drugs") and tobacco (one of the exposure variables). Questions were structured according to recommendations of the World Health Organization $(\mathrm{WHO})$ for studies on drug use with students. For each substance, participants were asked if they had already tried it (lifetime use) and about its use in the last 12 months (last year use) and in the last 30 days (last month use) prior to the survey ${ }^{12}$. This standard allows comparability with most studies on drug use, regardless of population, country or culture.

Social, economic, demographic and behavioral data were also collected as independent variables, namely: sex; age; skin color (self-reported); family income (in reais); mean of parents educational level (arithmetic mean of mother and father years of education); city/state that lived prior to the university entry (academic migration); living situation; marital status; illicit drug use by relatives and by friends; religious practice; tobacco use in the last year. We conducted a pilot study in the Federal University of Pelotas with dental and physical education undergraduate students to identify interpretation problems, which were further corrected for the final version of the instrument.

\section{Procedures}

Fieldwork was carried out between April and June of 2015. We contacted all professors in charge of the chosen subjects and scheduled day and time of application of the instrument in the class. All fieldwork was conducted by masters students, working in pairs during the three shifts (morning, afternoon and evening) on pre-defined work scales. Each applicator received a folder containing the "Applicant Handbook" with general instructions on the procedures to be followed during the visits and records for control of information about the class, namely: date of visit, subject system code, number of students enrolled, of present students, of absentees and refusals, of individuals under 18 years old, of dropouts (con- sidered those that formerly abandoned the subject or that had less than $50 \%$ of presence at the moment), and students that had already answered questionnaire in another subject. Visits to classes were standardized, starting with a presentation of aims and purposes of the study and confidentiality measures. Undergraduates were informed that their participation was voluntary and non-participation would not entail any individual losses. Those who agreed to participate signed a free and informed consent form.

After answering the questionnaire, the participants deposited it directly in a sealed box in order to increase confidentiality and reliability of responses. Each class was visited at least twice. After two visits, those classes with more than 10 missing students were visited again. Individuals who were not found in all visits or who refused to participate were considered as losses. Data were double typed by different professionals through Epidata software, version 3.1 (Epidata Association, Odense, Denmark).

\section{Statistical analysis}

Statistical analyzes were performed on Stata IC 13.1 software (Stata Corp., College Station, USA). Univariate analysis was conducted to describe the sample and to calculate prevalence of illicit drugs use in the lifetime, last year and last month, discriminated by type. Crude and adjusted analyzes were performed through the Poisson regression with robust adjustment for variance ${ }^{13}$, using as outcome the use in the last year of the combined category of illicit drugs. We used the Wald's test for heterogeneity and for linear trend for ordinal variables. Differences between categories were described in prevalence ratios (PR), with respective 95\% confidence intervals $(95 \% \mathrm{Cl})$ and $\mathrm{p}$ values.

For multivariate analysis, we elaborated a hierarchical model of analysis. Variables were selected through the backward method. Only those with $p$ value $\leq 0.2$ were maintained in the model, being considered as possible confounders. Estimates were calculated taking into account design effect. Level of significance was set as 5\% for two-tailed tests.

\section{Ethical considerations}

Participation was voluntary and individuals who agreed to participate were asked to sign a free and informed consent form. This study was approved by FURG Research Ethics Committee in the Health Area (registration number 37/2015).

\section{RESULTS}

One hundred and one classes were contacted. Eight were excluded due to the absence of students enrolled. Final sample was composed of 93 classes. In total, 2,459 enrollments were counted, of which 721 were ineligible (251 students enrolled in more than one class, 54 with less than 18 years and 416 
who had canceled enrollment or dropped out at the time of the research). Thus, this study had 1,738 eligible individuals (average of 19 students per class). A total of 1,423 undergraduates participated, representing a response rate of $81.9 \%$ and $18.1 \%$ of losses (15.6\% not found and $2.5 \%$ refusals).

Table 1 indicates that sample were consisted mainly by students aged 18 to 24 years (63.4\%), with white skin color (78.6\%), having no predominance between the sexes. Almost half of the students migrated from their cities to study (43.8\%), and approximately two fifths of the sample did not live with relatives (34.2\%). Median family income was $R \$ 3,000$ (equivalent to approximately 3.8 Brazilian minimum wages, or to US\$1,000 using as reference the June/2015 dollar quotation; interquartile range $=\mathrm{R} \$ 1,500-\mathrm{R} \$ 5,764$ ) and the mean of parents educational level was 10.8 years of study (SD = 4.5). Two-thirds of the sample reported having a friend who had used some illicit drug and $12.9 \%$ reported having a relative with this type of use. In addition, 39.8\% reported not having a religious practice. Furthermore, frequency of tobacco use in the last year was $21.4 \%$ (95\% Cl 19.3-23.6).

Table 2 shows pooled and specific prevalence of illicit drugs use in the lifetime, last year and last month. Considering use in the lifetime, the most prevalent was marijuana, followed by cocaine, LSD, ecstasy, inhalants, mushrooms and crack. For the use in the last year and last month, marijuana was also the most prevalent, followed by LSD, ecstasy, cocaine, mushrooms, inhalants and crack. It is noteworthy that no cases of crack use in the last year and last month were observed. Prevalence of the pooled category of illicit drugs use in the lifetime, last year and last month were 42.4\% (95\% Cl 39.8-45.0), 25.5\% (95\% Cl 23.2-27.8) and 17.7\% (95\% Cl 15.7-19.7), respectively.

Table 3 presents frequency of use in the last year of illicit drugs by categories and results of crude and adjusted analyzes for illicit drug use in the last year. Prevalence ranged from 5.5\% among those who reported not having friends that used illicit drugs to $60.8 \%$ among those who reported tobacco use in the last year. In the crude analysis, only the variables family income and skin color were not associated to the outcome of interest, remaining the same in the adjusted analysis. Thus, the following variables were identified as risk factors for illicit drugs use in the last year: being male (RP = $1.59 ; 95 \% \mathrm{Cl}=1.31-1.93)$; live with peers ( $\mathrm{RP}=1.56,95 \% \mathrm{Cl}=$ 1.16-2.09); being single ( $P R=1.41,95 \% \mathrm{Cl}=1.15-1.72)$; having a relative who had ever used illicit drug $(\mathrm{RP}=1.84,95 \% \mathrm{Cl}=$ 1.51-2.24), and having a friend who had ever used illicit drug $(\mathrm{RP}=4.38,95 \% \mathrm{Cl}=2.91-6.60)$. It was also observed that the probability of illicit drugs use in the last year was higher as the lower the age $(p<0.001)$, the higher the mean of parents educational level $(p=0.024)$, the lower the religious practice $(p<0.001)$. Academic migration was also a risk factor, as the probability of illicit drug use in the last year was higher as farther the distance of the student's previous city $(p=0.003)$.
Table 1. Description of FURG undergraduate students sample according to demographic, socioeconomic and behavioral variables ( $\mathrm{N}=1,423)$. Rio Grande, Brazil. 2015

\begin{tabular}{|c|c|c|}
\hline Variable & $\mathrm{n}$ & $\%$ \\
\hline \multicolumn{3}{|l|}{$\operatorname{Sex}(N=1,401)$} \\
\hline Female & 711 & 50.7 \\
\hline Male & 690 & 49.3 \\
\hline \multicolumn{3}{|l|}{ Age $(N=1,307)$} \\
\hline 18 to 24 years & 829 & 63.4 \\
\hline 25 to 31 years & 258 & 19.7 \\
\hline 32 years or more & 220 & 16.9 \\
\hline \multicolumn{3}{|l|}{ Skin color $(N=1,410)$} \\
\hline White & 1,109 & 78.6 \\
\hline Black & 94 & 6.7 \\
\hline Brown or yellow & 207 & 14.7 \\
\hline \multicolumn{3}{|c|}{ Academic migration $(\mathrm{N}=1,387)$} \\
\hline City of the university & 780 & 56.2 \\
\hline Neighbor cities & 111 & 8.0 \\
\hline Cities of the same state & 280 & 20.2 \\
\hline Cities of other states & 216 & 15.6 \\
\hline \multicolumn{3}{|l|}{ Living situation $(\mathrm{N}=1,390)$} \\
\hline Live with relatives & 915 & 65.8 \\
\hline Live alone & 177 & 12.8 \\
\hline Live with peers & 298 & 21.4 \\
\hline \multicolumn{3}{|l|}{ Marital status $(\mathrm{N}=1,412)$} \\
\hline Single & 595 & 42.1 \\
\hline In a relationship & 817 & 57.9 \\
\hline \multicolumn{3}{|c|}{ Relatives that used illicit drugs $(\mathrm{N}=1,399)$} \\
\hline No & 1,219 & 87.1 \\
\hline Yes & 180 & 12.9 \\
\hline \multicolumn{3}{|c|}{ Friend that used illicit drugs $(N=1,408)$} \\
\hline No & 511 & 36.3 \\
\hline Yes & 897 & 63.7 \\
\hline \multicolumn{3}{|c|}{ Religious practice $(N=1,414)$} \\
\hline Never & 563 & 39.8 \\
\hline Annually & 343 & 24.3 \\
\hline Monthly & 265 & 18.7 \\
\hline Weekly or daily & 243 & 17.2 \\
\hline \multicolumn{3}{|c|}{ Tobacco use in the last year $(\mathrm{N}=1,418)$} \\
\hline No & 1,114 & 78.6 \\
\hline Yes & 304 & 21.4 \\
\hline
\end{tabular}

Table 2. Prevalence of illicit drug use in the lifetime, last year and last month among FURG undergraduate students $(N=1,423)$. Rio Grande, Brazil. 2015

\begin{tabular}{lccc}
\hline & $\begin{array}{c}\text { Lifetime } \\
\%(95 \% \mathrm{Cl})\end{array}$ & $\begin{array}{c}\text { Last year } \\
\%(95 \% \mathrm{Cl})\end{array}$ & $\begin{array}{c}\text { Last month } \\
\%(95 \% \mathrm{Cl})\end{array}$ \\
\hline Illicit drugs & $42.4(39.8-45.0)$ & $25.5(23.2-27.8)$ & $17.7(15.7-19.7)$ \\
Types* & & & \\
$\quad$ Marijuana & $40.5(37.9-43.1)$ & $23.9(21.7-26.1)$ & $16.8(14.8-18.8)$ \\
Inhalants & $8.8(7.3-10.3)$ & $2.1(1.4-2.8)$ & $0.9(0.4-1.4)$ \\
Cocaine & $10.9(9.3-12.5)$ & $3.5(2.5-4.5)$ & $1.3(0.7-1.9)$ \\
Crack & $0.6(0.2-1.0)$ & 0.0 & 0.0 \\
Mushrooms & $6.4(5.1-7.7)$ & $2.8(1.9-3.7)$ & $1.4(0.8-2.0)$ \\
Ecstasy & $9.1(7.6-10.6)$ & $4.6(3.5-5.7)$ & $2.0(1.3-2.7)$ \\
LSD & $9.8(8.3-11.3)$ & $5.9(4.7-7.1)$ & $2.8(1.9-3.7)$ \\
\hline
\end{tabular}

\%: prevalence; $95 \%$ Cl: $95 \%$ confidence interval. * Multiple answers. 
Table 3. Crude and adjusted prevalence ratio for associations between illicit drugs use in the last year and independent variables. Multivariate analysis conducted with four hierarchical levels, through Poisson regression with robust adjust for variance, accounting for design effect. Sample of FURG undergraduate students ( $N=1,423)$. Rio Grande, Brazil. 2015

\begin{tabular}{|c|c|c|c|c|}
\hline \multirow{2}{*}{ Level } & \multirow{2}{*}{ Variable } & \multirow{2}{*}{$\%$} & Crude & Adjusted \\
\hline & & & PR (95\% Cl) & $\operatorname{PR}(95 \% \mathrm{Cl})$ \\
\hline \multirow[t]{15}{*}{$1^{\text {st }}$} & Sex & & $\mathrm{p}<0.001$ & $\mathrm{p}<0.001$ \\
\hline & Female & 20.6 & 1 & 1 \\
\hline & Male & 30.6 & $1.50(1.23-1.83)$ & $1.59(1.31-1.93)$ \\
\hline & Age & & $p<0.001^{*}$ & $p<0.001^{*}$ \\
\hline & 18 to 24 years & 32.9 & $4.96(2.92-8.42)$ & $4.82(2.87-8.12)$ \\
\hline & 25 to 31 years & 17.5 & $2.62(1.50-4.56)$ & $2.45(1.40-4.28)$ \\
\hline & 32 or more & 6.5 & 1 & 1 \\
\hline & Skin color & & $p=0.147$ & $\mathrm{p}=0.695$ \\
\hline & White & 26.5 & 1 & 1 \\
\hline & Black, brown or yellow & 22.3 & $0.84(0.67-1.06)$ & $0.95(0.75-1.21)$ \\
\hline & Family income & & $p=0.324$ & $p=0.419$ \\
\hline & $1^{\text {st }}$ quartile (low) & 25.3 & 1 & 1 \\
\hline & $2^{\text {nd }}$ quartile & 23.9 & $0.96(0.74-1.24)$ & $1.06(0.81-1.40)$ \\
\hline & $3^{\text {rd }}$ quartile & 23.8 & $0.94(0.70-1.27)$ & $0.98(0.74-1.31)$ \\
\hline & $4^{\text {th }}$ quartile (high) & 29.4 & $1.16(0.91-1.48)$ & $1.18(0.92-1.51)$ \\
\hline \multirow[t]{8}{*}{$2^{\text {nd }}$} & Parents educational level & & $\mathrm{p}<0.001^{*}$ & $p=0.024^{*}$ \\
\hline & $1^{\text {st tercile (low) }}$ & 17.5 & 1 & 1 \\
\hline & $2^{\text {nd }}$ tercile & 24.9 & $1.42(1.08-1.86)$ & $1.09(0.81-1.47)$ \\
\hline & $3^{\text {rd }}$ tercile (high) & 34.9 & $1.97(1.49-2.62)$ & $1.37(1.02-1.85)$ \\
\hline & Academic migration & & $\mathrm{p}<0.001^{*}$ & $p=0.003^{*}$ \\
\hline & City of the university or neighbor cities & 20.5 & 1 & 1 \\
\hline & Cities of the same state & 31.8 & $1.55(1.20-1.99)$ & $1.25(0.97-1.59)$ \\
\hline & Cities of other states & 36.7 & $1.78(1.41-2.24)$ & $1.40(1.10-1.79)$ \\
\hline \multirow[t]{13}{*}{$3^{\text {rd }}$} & Living situation & & $\mathrm{p}<0.001$ & $p=0.013$ \\
\hline & Live with relatives & 19.1 & 1 & 1 \\
\hline & Live alone & 34.3 & $1.78(1.37-2.32)$ & $1.30(0.92-1.83)$ \\
\hline & Live with peers & 39.9 & $2.07(1.65-2.60)$ & $1.56(1.16-2.09)$ \\
\hline & Marital status & & $\mathrm{p}<0.001$ & $p=0.001$ \\
\hline & Single & 19.9 & $1.70(1.41-2.04)$ & $1.41(1.15-1.72)$ \\
\hline & In a relationship & 33.3 & 1 & 1 \\
\hline & Relatives that used illicit drugs & & $\mathrm{p}<0.001$ & $\mathrm{p}<0.001$ \\
\hline & No & 23.0 & 1 & 1 \\
\hline & Yes & 44.4 & $1.92(1.58-2.33)$ & $1.84(1.51-2.24)$ \\
\hline & Friend that used illicit drugs & & $\mathrm{p}<0.001$ & $\mathrm{p}<0.001$ \\
\hline & No & 5.5 & 1 & 1 \\
\hline & Yes & 37.4 & $6.70(4.35-10.34)$ & $4.38(2.91-6.60)$ \\
\hline \multirow[t]{8}{*}{$4^{\text {th }}$} & Religious practice & & $\mathrm{p}<0.001^{*}$ & $p=0.003^{*}$ \\
\hline & Never & 37.2 & 1 & 1 \\
\hline & Annually & 22.9 & $0.62(0.48-0.81)$ & $0.88(0.70-1.10)$ \\
\hline & Monthly & 19.2 & $0.53(0.39-0.72)$ & $0.90(0.71-1.16)$ \\
\hline & Weekly or daily & 9.2 & $0.25(0.16-0.39)$ & $0.53(0.35-0.81)$ \\
\hline & Last year use of tobacco & & $\mathrm{p}<0.001$ & $\mathrm{p}<0.001$ \\
\hline & No & 15.9 & 1 & 1 \\
\hline & Yes & 60.8 & $3.81(3.25-4.46)$ & $2.55(2.11-3.09)$ \\
\hline
\end{tabular}

\%: outcome's prevalence by category; PR: prevalence ratio; $95 \%$ Cl: 95\% confidence interval.

*Wald's test for linear trend. 


\section{DISCUSSION}

Prevalence of illicit drug use by undergraduate students was high in all measures (use in the lifetime, last year and last month), being higher than the frequencies in the general population in Brazil' ${ }^{2}$. When comparing use of illicit drugs in the last year, the prevalence in this sample (25.5\%) was lower than the frequency of the Brazilian sample of university students $(35.8 \%)^{3}$. However, if we observe data by drug types, the prevalence found in our study were higher than the national sample, except for inhalants and crack. Therefore, the discrepancy is probably because the pooled category illicit drugs in the national survey includes several substances not evaluated in this research.

Marijuana had the highest frequency in this study. Although there is evidence that its use may be associated with a number of negative health outcomes ${ }^{14}$, acceptability of its recreational use has been increasing in recent years ${ }^{15}$. LSD and ecstasy also had a high prevalence. Both substances are related to raves and electronic parties, which are very common among the studied population ${ }^{16,17}$. Cocaine is a substance with less acceptability and with greater perception of risk associated with its use, which may explain its moderate prevalence in our sample ${ }^{15}$. Furthermore, we believe that the low frequency of crack and inhalants use is highly attributable to the high family income of this sample (median $=R \$ 3,000$, approximately US\$1,000), when compared to the income in the general population (median $=\mathrm{R} \$ 510$, approximately US\$ 170) ${ }^{18}$. These substances are known to be very cheap and of low quality, being commonly used by individuals of extreme vulnerability, such as the homeless population ${ }^{19}$.

Being male has shown to be a risk factor for the illicit drugs use in the last year, a result that has been consistently replicated ${ }^{9}$. It is plausible that males have a lower risk perception as well as a higher perception of easy access to the drug when compared to female ${ }^{20}$. The probability of illicit drugs use in the last year was also higher among single and younger respondents. It is possible that single and young individuals are more susceptible to the need for social acceptance, with also a greater sense of freedom and autonomy, which would foster development of risky behaviors, such as drug use $e^{9,21}$.

Family income was not associated with the outcome. A study with a national sample of Brazilian $9^{\text {th }}$ grade students points out that both extremes of the economic condition approximate individuals from contact with illicit substances, although through different mechanisms ${ }^{22}$. We hypothesized that this assumption may have dissolved the effect of this association in this sample.

However, it was identified that respondents whose parents had higher educational level were more likely to have illicit drugs use in the last year. This result was not expected, since parents with more years of formal schooling supposed to have more knowledge and, consequently, better parental support strategies ${ }^{23}$. This association has also been identified both in the research with school children of Brazil ${ }^{22}$ and of United States ${ }^{24}$. On one hand, the higher educational level of the parents may be related to higher workloads and, consequently, less time dedicated to monitoring ${ }^{23}$. On the other hand, even though no association with income was established in this study, higher parental educational level may be associated with greater purchasing power and, therefore, easier access to drugs and lower perception of risk ${ }^{24}$.

The higher the frequency of religious practice reported, the lower the probability of illicit drugs use in the last year in this sample. Individuals with weekly or daily religious practice presented a reduction of $47 \%$ in probability of this use when compared to those who never attend to religious ceremonies. These results are in line with other researches with this population ${ }^{5,25}$. Values presented during religious practices can influence individual's personality and the way they make decisions, fostering self-control and reducing chances of deviations of behavior (such as illicit drug use ${ }^{26}$.

Students who reported tobacco use in the last year had a nearly three-fold higher probability of illicit drugs use in the last year. This relationship has also been observed in other studies with this subject $t^{9,27,28}$. Researches suggest that first use of an illegal substance is often preceded by use of licit substances, such as tobacco 9,28.

Academic migration within the country is the main issue of this research. We hypothesized that this migration may be contributing to use of illicit drugs in university context. We found that almost half of respondents migrated from their cities to study at the university, which might be a possible reflection of admission process through ENEM. In addition, we identified that the greater the distance from the city of origin, the greater the probability of illicit drugs use in the last year. This association can be interpreted by three phenomena: distance from family context; peer influence; and deprivation of psychosocial integration.

Firstly, surveys carried with this population indicate the protective role in living with relatives ${ }^{9,29}$, which was also seen in our study. We have identified only one research, conducted with Southeast Asian undergraduate students, in which being living with relatives would be a risk factor, although authors argue that this result was the opposite of what was expected ${ }^{30}$. It is possible that the presence of relatives reduces the likelihood of illicit drug use due to support, monitoring, norms and influences that family exerts ${ }^{9,31}$. Individuals who migrated from their cities are distant from their family and hence with less contact with this protective factor. However, when discussing the family, it is important to make an observation. Individuals who reported having relatives who had used illicit drugs showed a prevalence of illicit drugs use in the last year almost twice as large as the reference 
group. These combined results indicate that the family can represent both a risk and/or a protective factor, since there is a predisposition for individuals to learn and model their behaviors with negative and/or positive examples learned in the family ${ }^{32}$. Notwithstanding, genetic influences should also be taken into account. Studies have described an important role of genetics from drug initiation ${ }^{33}$ to dependence ${ }^{34}$, which might explain part of this association.

The second is the increase in the number of individuals living with peers. Respondents in this category had a 56\% higher probability to have illicit drugs use in the last year than those who reported living with their relatives. In addition, two thirds of the students reported having friends who had used drugs, and this subgroup presented a prevalence almost five times higher than the reference group. We believe that this influence occurs in several cultural contexts, since similar results were found in other studies with university students in Brazil', United States ${ }^{31}$ and Ethiopia ${ }^{32}$, for instance. Both social causation and social selection can play a role. By the perspective of the social causation, the need for acceptance, increased desire to fit it and the predisposition to model behaviors according to peers may shed a light on this association $n^{4,32,35}$. However, substance users tend to gravitate toward individuals with similar behaviors, socially selecting their peers, which can be a plausible explanation of this association ${ }^{35,36}$.

The third phenomenon is that academic migration within the country can generate a deprivation of psychosocial integration. Brazil is a very wide country with extreme cultural diversity in its territory. It is possible that the greater the distance covered in this migration, the greater the geographic distance from their families, their culture and their social context, which might explain this dose-response effect. This situation can generate a distressful background. Several studies have pointed to high prevalence of mental disorders such as depression and anxiety in the university setting ${ }^{37,38}$. Drug use could serve as a way of coping with these difficulties ${ }^{39}$. Nevertheless, there is a lack of studies targeting the association between within-country academic migration and development of mental health problems, especially in Brazil. Future research can elucidate this question, providing information to intervention to both issues - mental disorders and drug use.

Cross-sectional design has shown to be adequate to answer the questions of this research. However, there are limitations. First, it is not possible to make causal inferences because both dependent and independent variables were collected at the same time, not allowing establishing temporal relationship. Therefore, associations between outcome and independent behavioral variables, such as religious practice and tobacco use are susceptible to reverse causality bias and should be interpreted with caution. Secondly, it is possible that prevalence of illicit drug use is underreported due to occurrence of false response bias and to exclusion of individuals who dropped out at the time of data collection. Thirdly, psychiatric comorbidities were not assessed, which might be a possible confounding variable. Lastly, this study had a higher response rate than the survey with a representative sample of Brazilian university students ${ }^{40}$, which indicates success in the strategy to reduce losses.

\section{CONCLUSIONS}

Present study showed that use of illicit drugs in this sample was high in all of its measures (use in the lifetime, last year and last month), when compared to the general population and to Brazilian university students. Marijuana had the highest prevalence, followed by LSD, ecstasy and cocaine. We highlight that academic migration within Brazil might have contributed to the high frequency of illicit drugs use in this sample. This might have happened due to the increase in the distance from the family context, to the raise in the number of individuals living with peers and to geographical and cultural detachment, which might develop a distressful background. This study also presented that being male, younger, single, with parents with high educational level, with friends and relatives who used illicit drugs and with tobacco use in the last year increases the probability of use in the last year of illicit drugs. Only religious practice showed a protective effect on this outcome. Results suggest the need to implement intersectoral policies that consider health in a broad and comprehensive way. Thus, we recommend the conduction of systematic epidemiological evaluations of drugs use in order to provide precise information to stakeholders. Also, implementation of evidence-based prevention strategies that consider social and cultural aspects of university setting and improvement of mental health treatment and referral systems. Lastly, it is fundamental to invest in optimal conditions of access to culture, leisure and housing. These interventions should consider specific needs of those individuals who migrated from their cities to study at the university. This subgroup is more exposed to main risk factors pointed out by this research and hence to the use of illicit drugs.

\section{INDIVIDUAL CONTRIBUTIONS}

Lauro Miranda Demenech, Samuel C. Dumith and Lucas Neiva-Silva - Contributed in the conception and design of the study, in data analysis and interpretation, and in drafting and revising the paper.

Luiza Santos Ferreira, Mariana Lima Corrêa, Pedro San Martin Soares and Priscila Arruda da Silva Contributed in data analysis and interpretation, and in the drafting of the paper. All authors approved the final version. 


\section{CONFLICTS OF INTEREST}

The authors report no conflicts of interest.

\section{ACKNOWLEDGEMENTS}

This study is the result of a master's dissertation of the first author, who received a scholarship from Capes (Coordenação de Aperfeiçoamento de Pessoal do Nível Superior). The second author is a research productivity fellow at CNPq (ConseIho Nacional de Desenvolvimento Científico e Tecnológico).

\section{REFERENCES}

1. United Nations Office on Drugs and Crime. World Drug Report 2016. New York: United Nations; 2016.

2. II Levantamento Nacional de Álcool e Drogas (LENAD) - 2012. Laranjeira R, et al. (Supervisão). São Paulo: Instituto Nacional de Ciência e Tecnologia para Políticas Públicas de Álcool e Outras Drogas (INPAD), Unifesp; 2014.

3. Andrade AG, Duarte PCAV, Oliveira LG (Orgs.). I Levantamento Nacional Sobre o Uso de Álcool, Tabaco e Outras Drogas Entre Universitários das 27 Capitais Brasileiras. São Paulo: Secretaria Nacional de Políticas sobre Drogas (SENAD); 2010.

4. Zeferino MT, Hamilton H, Brands B, Wright MGM, Cumsille F, Khenti A. Consumo de drogas entre estudantes universitários: família, espiritualidade e entretenimento moderando a influência dos pares. Texto Contexto Enferm. 2015;24(spe):125-35.

5. Gomes FC, Andrade AG, Izbicki R, Moreira-Almeida A, Oliveira LG. Religion as a protective factor against drug use among Brazilian university students: a national survey. Rev Bras Psiquiatr. 2013;35(1):29-37.

6. Dennhardt AA, Murphy JG. Prevention and treatment of college student drug use: A review of the literature. Addict Behav. 2013;38(10):2607-18.

7. Eckschmidt F, Andrade AG, Oliveira LG. Comparação do uso de drogas entre universitários brasileiros, norte-americanos e jovens da população geral brasileira. J Bras Psiquiatr. 2013;62(3):199-207.

8. Gasparotto GS, Fantineli ER, Campos W. Tobacco use and alcohol consumption associated with sociodemographic factors among college students. Acta Scientiarum Health Sciences. 2015;37(1)

9. El Ansari W, Vallentin-Holbech L, Stock C. Predictors of Illicit Drug/s Use Among University Students in Northern Ireland, Wales and England. Glob J Health Sci. 2014;7(4):18-29.

10. Andriola WB. Doze motivos favoráveis à adoção do Exame Nacional do Ensino Médio (ENEM) pelas Instituições Federais de Ensino Superior. Ensaio Aval Pol Públ Educ. 2011:19(70):107-25

11. Alexander BK. The globalisation of addiction: a study in poverty of the spirit. New York: Oxford University Press; 2008. 421p.

12. World Health Organization. A methodology for student drug-use surveys. Geneva: WHO: 1980.

13. Barros AJD, Hirakata VN. Alternatives for logistic regression in cross-sectional studies: an empirical comparison of models that directly estimate the prevalence ratio. BMC Med Res Methodol. 2003;3:21.

14. Nugent SM, Morasco BJ, O'Neil ME, Freeman M, Low A, Kondo K, et al. The Effects of Cannabis Among Adults With Chronic Pain and an Overview of General Harms: A Systematic Review. Ann Intern Med. 2017;167(5):319-31

15. Johnston LD, O'Malley PM, Bachman JG, Schulenberg JE, Miech RA. Monitoring the future - National survey results on drug use, 1975-2015: Volume 2, College students and adults age 19-55. Ann Arbor: Institute for Social Research; 2016.

16. Edland-Gryt M, Sandberg S, Pedersen W. From ecstasy to MDMA: Recreational drug use, symbolic boundaries, and drug trends. Int I Drug Policy. 2017:50:1-8.
17. Palamar JJ, Griffin-Tomas M, Ompad DC. Illicit drug use among rave attendees in a nationally representative sample of US high school seniors. Drug Alcohol Depend. 2015;152:24-31.

18. Instituto Brasileiro de Geografia e Estatística. Censo Demográfico 2010: Características da população e dos domicílios. Rio de Janeiro: IBGE; 2011.

19. Moura YG, Sanchez ZM, Opaleye ES, Neiva-Silva L, Koller SH, Noto AR. Drug use among street children and adolescents: what helps? Cad Saúde Pública. 2012;28(7):1371-80.

20. Hynes M, Demarco M, Araneda JC, Cumsille F. Prevalence of marijuana use among university students in Bolivia, Colombia, Ecuador, and Peru. Int J Environ Res Public Health. 2015;12(5):5233-40.

21. Machado CS, Moura TM, Almeida RJ. Estudantes de Medicina e as Drogas: Evidências de um Grave Problema. Rev Bras Educ Med. 2015;39(1):159-67.

22. Horta RL, Horta BL, Costa AWN, Prado RR, Oliveira-Campos M, Malta DC. Lifetime use of illicit drugs and associated factors among Brazilian schoolchildren, National Adolescent School-based Health Survey (PeNSE 2012). Rev Bras Epidemiol. 2014;17(SSupl 1):31-45.

23. Brito ALS, Hardman CM, Barros MVG. Prevalence and factors associated with the co-occurrence of health risk behaviors in adolescents. Rev Paul Pediatria. 2015:33(4):423-30.

24. Humensky JL. Are adolescents with high socioeconomic status more likely to engage in alcohol and illicit drug use in early adulthood? Subst Abuse Treat Prev Policy. 2010;5:19.

25. Yeung JW, Chan YC, Lee BL. Youth religiosity and substance use: a meta-analysis from 1995 to 2007. Psychol Rep. 2009;105(1):255-66.

26. Kelly E, Polanin JR, Jang SJ, Johnson BR. Religion, Deliquency, and Drug Use: A MetaAnalysis. Criminal Justice Review. 2015;40(4).

27. Castaldelli-Maia JM, Martins SS, de Oliveira LG, de Andrade AG, Nicastri S. The role of drug use sequencing pattern in further problematic use of al cohol, tobacco, cannabis, and other drugs. J Ment Health. 2015;24(1):9-14

28. Redner R, White TJ, Harder VS, Higgins ST. Vulnerability to Smokeless Tobacco Use Among Those Dependent on Alcohol or Illicit Drugs. Nicotine Tob Res. 2014;16(2):216-23.

29. Mohammadpoorasl A, Ghahramanloo AA, Allahverdipour H, Augner C. Substance abuse in relation to religiosity and familial support in Iranian college students. Asian J Psychiatr. $2014 \cdot 9 \cdot 41-4$

30. Yi S, Peltzer K, Pengpid S, Susilowati IH. Prevalence and associated factors of illicit drug use among university students in the association of southeast Asian nations (ASEAN). Subst Abuse Treat Prev Policy. 2017;12:9.

31. Pinchevsky GM, Arria AM, Caldeira KM, Garnier-Dykstra LM, Vincent KB, O'Grady KE. Marijuana exposure opportunity and initiation during college: parent and peer influences. Prev Sci. 2012;13(1): 43-54.

32. Kassa A, Taddesse F, Yilma A. Prevalence and factors determining psychoactive substance (PAS) use among Hawassa University (HU) undergraduate students, Hawassa Ethiopia. BMC Public Health. 2014;14:1044

33. Richmond-Rakerd LS, Slutske WS, Lynskey MT, Agrawal A, Madden PAF, Bucholz KK, et al. Age at first use and later substance use disorder: Shared genetic and environmental pathways for nicotine, alcohol, and cannabis. J Abnorm Psychol. 2016;125(7):946-59.

34. Palmer RHC, Brick L, Nugent NR, Bidwell LC, McGeary JE, Knopik VS, et al. Examining the role of common genetic variants on al cohol, tobacco, cannabis and illicit drug dependence: genetics of vulnerability to drug dependence. Addiction. 2015;110(3):530-7.

35. Van Ryzin MJ, Fosco GM, Dishion TJ. Family and peer predictors of substance use from early adolescence to early adulthood: An 11-year prospective analysis. Addict Behav. 2012;37(12):1314-24.

36. Fergusson DM, Horwood LJ. Prospective Childhood Predictors of Deviant Peer Affiliations in Adolescence. J Child Psychol Psychiatry. 1999;40(4):581-92.

37. Auerbach RP, Alonso J, Axinn WG, Cuijpers P, Ebert DD, Green JG, et al. Mental disorders among college students in the World Health Organization World Mental Health Surveys. Psychol Med. 2016;46(14):2955-70.

38. Pacheco JP, Giacomin HT, Tam WW, Ribeiro TB, Arab C, Bezerra IM, et al. Mental health problems among medical students in Brazil: a systematic review and meta-analysis. Rev Bras Psiquiatr. 2017:39(4):369-78.

39. Hyman SM, Sinha R. Stress-Related Factors in Cannabis Use and Misuse: Implications for Prevention and Treatment. J Subst Abuse Treat. 2009:36(4):400-13.

40. Castaldelli-Maia JM, Martins SS, Oliveira LG, Van Laar M, Andrade AG, Nicastri S. Use transition between illegal drugs among Brazilian university students. Soc Psychiatry Psychiatr Epidemiol. 2014; 49(3):385-94. 